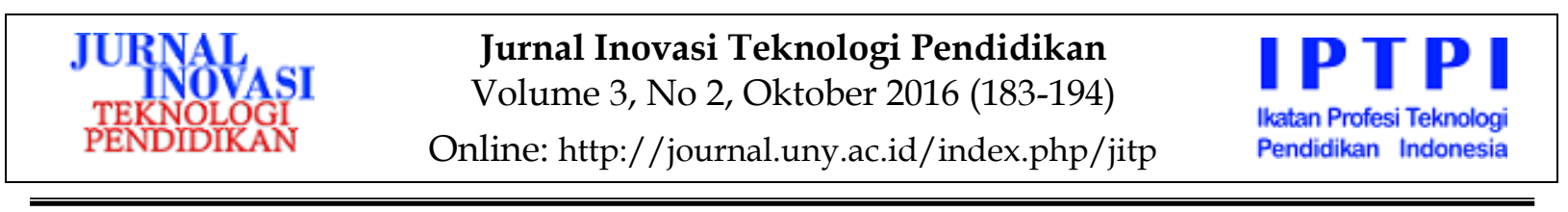

\title{
PENGEMBANGAN MULTIMEDIA PEMBELAJARAN AKUNTANSI PAJAK DENGAN PENDEKATAN QUANTUM LEARNING DI SMK
}

\author{
Fitria Yuniarti, Herminarto Sofyan \\ Prodi Teknologi Pembelajaran PPs UNY, FT Universitas Negeri Yogyakarta \\ fitriayuniarti26@gmail.com, hermin@uny.ac.id
}

\begin{abstract}
Abstrak
Penelitian ini bertujuan untuk: (1) menghasilkan produk multimedia pembelajaran akuntansi pajak dengan pendekatan quantum learning, (2) mengungkapkan kualitas kelayakan multimedia pembelajaran akuntansi pajak, (3) mengungkapkan keefektivan multimedia pembelajaran akuntansi pajak di Kelas XI SMK Negeri 1 Depok Yogyakarta. Multimedia pembelajaran ini dikembangkan dengan pendekatan quantum learning yang dikembangkan menggunakan software Adobe Flash CS6. Studi ini merupakan penelitian dan pengembangan (R\&D) dengan prosedur pengembangan yang mengadopsi model pengembangan Alessi dan Trollip, yaitu perencanaan, desain, dan pengembangan. Validasi produk dilakukan pada tahap uji alpha yang melibatkan dua ahli media dan dua ahli materi. Sementara uji beta melibatkan tiga orang siswa. Produk yang dikembangkan telah layak digunakan dengan perolehan skor hasil validasi ahli media 4,1 dengan kategori baik, validasi ahli materi 4,0 dengan kategori baik, dan penilaian siswa pada uji beta 4,5 dengan kategori sangat baik. Multimedia pembelajaran akuntansi pajak dinilai efektif karena dapat meningkatkan hasil belajar kognitif siswa dengan nilai rata-rata pretest 59,8, dan nilai ratarata posttest 85,6 . Terjadi peningkatan pencapaian sebesar $25,8 \%$ dari 30 orang siswa hanya satu orang siswa yang tidak tuntas dalam proses pembelajaran.
\end{abstract}

Kata kuci: multimedia, akuntansi pajak, quantum learning

\section{DEVELOPING MULTIMEDIA FOR TAX ACCOUNTING TEACHING WITH THE QUANTUM LEARNING APPROACH AT VOCATIONAL HIGH SCHOOL}

\author{
Fitria Yuniarti, Herminarto Sofyan \\ Prodi Teknologi Pembelajaran PPs UNY, FT Universitas Negeri Yogyakarta \\ fitriayuniarti26@gmail.com, hermin@uny.ac.id
}

\section{Abstract}

This research aims to: (1) develop a multimedia product for tax accounting teaching with the quantum learning approach, (2) reveal the feasibility quality of the developed multimedia for tax accounting teaching, (3) reveal the effectiveness of the developed multimedia for tax accounting teaching to the $11^{\text {th }}$ grade students of State Vocational High School 1 Depok, Yogyakarta. This learning multimedia was developed by the quantum learning approach using Adobe Flash CS6 software. This study is research and development $(R \in D)$ with the procedure on the development adopted from Alessi and Trollip models, namely planning, design, and development. The validation of the product was conducted in the alpha test phase involving two media experts and two material experts. Meanwhile, the beta test involved three students. The developed product is proper to be used with the validity score of 4.1 by the media experts (good category), by experts' validation material 4.0 of (good category), and assessment of students in the beta test of 4.5 (very good category); (3) the multimedia for tax accounting teaching is effective because it can increase students' cognitive learning outcomes. This is evidenced by the average score of 59.8 on pretest and posttest average score of 85.6. There is an increase by $25.8 \%$ of the 30 students, and only one student do not achieve the standard mastery.

Keywords: multimedia, tax accounting, quantum learning 


\section{Pendahuluan}

Sekolah Menengah Kejuruan (SMK) merupakan jalur pendidikan formal yang mengelola berbagai program keahlian. Penjelasan Pasal 15 UU SISDIKNAS No. 20 tahun 2003 tentang Sekolah Menengah Kejuruan menyebutkan bahwa SMK sebagai bentuk satuan pendidikan kejuruan merupakan pendidikan menengah yang mempersiapkan peserta didik terutama untuk bekerja dalam bidang tertentu.

Mata pelajaran untuk masing-masing bidang keahlian disesuaikan dengan program keahlian dan paket keahliannya. Akuntansi pajak merupakan mata pelajaran yang harus dikuasai kompetensinya oleh siswa pada bidang studi keahlian bisnis dan manajemen program studi keahlian keuangan, dan kompetensi keahlian akuntansi. Mata pelajaran akuntansi pajak merupakan mata pelajaran yang mempelajari dasar-dasar pajak, peraturan-peraturan perpajakan hingga perhitungan pajak dan cara melaporkan pajak.

SMK Negeri 1 Depok Yogyakarta merupakan Sekolah Menengah Kejuruan yang memiliki bidang keahlian bisnis dan manajemen, program keahlian keuangan, dan paket keahlian akuntansi. Mata pelajaran akuntansi pajak merupakan salah satu mata pelajaran pada paket keahlian akuntansi di Kelas XI SMK Negeri 1 Depok. Salah satu indikator siswa mampu menguasai mata pelajaran administrasi pajak adalah hasil belajar siswa yang mencapai Kriteria Ketuntasan Minimal (KKM). Kenyataanya tidak semua siswa mampu mencapai KKM yang ditetapkan. Pada tahun ajaran 2014/2015 hasil belajar siswa kelas XI dari keseluruhan jumlah siswa sebanyak 96 orang untuk mata pelajaran akuntansi pajak, 39 orang atau 40,6\% diantaranya tidak mencapai KKM, sisanya sebanyak 57 orang atau $59,4 \%$ berhasil mencapai KKM. Hal ini menjadi masalah khususnya bagi mata pelajaran akuntansi pajak.

Berdasarkan pengamatan yang dilakukan, diketahui bahwa kendala yang dihadapi pada proses pembelajaran akuntansi pajak yakni sebagai berikut: (1) banyaknya materi akuntansi pajak yang harus disampikan guru dan dipelajari siswa; (2) terbatasnya bahan ajar yang digunakan yaitu berupa buku teks dan media pembelajaran yang berupa slide presentasi power point; (3) tampilan media pembelajaran yang kurang menarik dengan warna-warna yang kurang variatif; (4) media pembelajaran yang digunakan tidak memberikan balikan positif ketika siswa mengerjakan soal-soal latihan; (5) media pembelajaran yang digunakan belum memfasilitasi keseluruhan gaya belajar siswa; (6) materi disampaikan menggunakan metode ceramah. Penyajian materi dalam buku teks dan slide presentasi power point dijabarkan secara deskriptif, sistematis dan monoton. Siswa kurang memahami inti materi yang disampaikan; (7) dalam menghafal materi, siswa tidak menggunakan teknik asosiasi (singkatan yang mudah diingat); (8) belum adanya multimedia pembelajaran interaktif yang digunakan sebagai bahan ajar ataupun media pembelajaran; (9) di kelas XII, siswa akan melakukan Praktik Kerja Lapangan (PKL) yang bertujuan untuk menerapkan ilmu yang diperoleh pada program keahlian akuntansi. Siswa akan lebih termotivasi dalam belajar apabila mengetahui manfaatnya dikemudian hari; dan (10) keterbatasan waktu yang tersedia di kelas dalam mempelajari akuntansi pajak juga menjadi kendala. Media pembeajaran yang tidak terikat waktu tentu dapat bermanfaat bagi siswa dalam mempelajari akuntansi pajak.

Kendala-kendala yang dihadapi selama proses pembelajaran pada mata pelajaran akuntansi pajak perlu diatasi dengan adanya multimedia pembelajaran yang dapat menyampaikan materi secara efektif, efisien, dan tepat serta penyajian materi yang menarik minat siswa dan tidak terikat pada alokasi waktu di kelas. Siswa dapat menggunakanya di rumah dan dapat diulang-ulang sesuai dengan tingkat pemahaman masing-masing siswa. "... salah satu media pembelajaran yang paling tepat 
adalah multimedia. Terlebih, ini adalah era digitalisasi, masa di mana multimedia memegang peranan penting dalam banyak aspek kehidupan. Banyak sekolah yang telah membuktikan bahwa pengajaran berbasis multimedia lebih efektif dan efisien." (Asmani, 2011, p.241).

Multimedia pembelajaran merupakan tampilan materi yang menggunakan kata-kata dan gambar-gambar. Kata-kata yang ditampilkan dapat dalam bentuk teks tertulis atau dapat juga teks yang dibacakan. Sementara itu gambar dapat berupa ilustasi, grafik, foto, peta, atau animasi dan video.

Dipilihnya quantum learning sebagai model desain penyampai pesan pada multimedia pembelajaran adalah karena quantum learning dapat membuat siswa senang belajar dan dapat belajar sesuai dengan gaya belajarnya masing-masing. "The Quantum Learning is a learning activity in a pleasant atmosphere. Quantum Learning is one of the teachings requiring freedom, relaxing, amazing, enjoyable, and stimulating conditions." (Suryani, 2013, p.56)

Quantum learning memiliki berbagai kelebihan yang diaplikasikan pada aspekaspek yang mendukung siswa untuk menyenangi belajar, sehingga diharapkan siswa akan dapat meningkatkan hasil belajarnya. Beberapa aspek-aspek yang terdapat pada quantum learning adalah (1) siswa akan mengetahui tujuan pembelajaran apabila diterapkan dalam kehidupan seharihari; (2) siswa akan mendapat balikan positif yang berfungsi untuk meningkatkan rasa percaya dirinya sehingga dapat melakukan yang terbaik dalam proses pembelajaran; (3) memunculkan ketertarikan siswa dalam belajar dan membuat siswa nyaman ketika mempelajari materi. Guru juga terbantu karena perhatian siswa lebih fokus sehingga materi yang disampaikan dapat terserap dengan baik; (4) siswa dapat belajar sesuai dengan gaya belajarnya sendiri; (5) penyajian materi dengan menggunakan teknik mind mapping untuk memudahkan siswa dalam menyerap inti materi yang disampaikan; (6) siswa dapat meng- hafal materi-materi dengan mudah dengan menggunakan teknik asosiasi. Semua kelebihan-kelebihan yang terdapat di dalam quantum learning diaplikasikan ke dalam pengembangan multimedia pembelajaran akuntansi pajak.

Pengembangan multimedia pembelajaran merupakan kajian pada suatu bidang ilmu, yaitu Teknologi Pembelajaran. Teknologi pembelajaran merupakan suatu disiplin ilmu yang bidang kajiannya menitikberatkan pada segala permasalahan yang menyangkut pembelajaran. Pada perkembangannya, AECT (Association for Educational Communications and Technology) tahun 1977 membagi dua kawasan yaitu kawasan teknologi pendidikan dan kawasan teknologi pembelajaran. Pada tahun 1994 AECT hanya memunculkan satu kawasan saja yaitu kawasan teknologi pembelajaran. Rumusan yang terbaru yaitu tahun 2004 AECT menggabungkan antara kawasan teknologi pendidikan dengan teknologi pembelajaran menjadi suatu kajian (the study) yang dirumuskan dalam suatu keterkaitan antara teori dan praktik. Rumusan AECT 2004 yaitu "Educational technology is the study and ethical practice of facilitating learning and improving performance by creating, using, and managing appropriate technological processes and resources." (Januszewski, 2008, p.1).

Proses creating yang disebutkan pada rumusan AECT 2004 berupa menciptakan atau mengembangkan bahan ajar guna kepentingan pembelajaran. Bahan ajar yang dikembangkan dapat berupa media pembelajaran maupun multimedia pembelajaran. Berdasarkan penjabaran mengenai Teknologi Pembelajaran maka mengembangkan multimedia pembelajaran yang efektif guna kepentingan pembelajaran merupakan salah satu bidang kajian Teknologi Pembelajaran.

Pengembangan multimedia pembelajaran dengan pendekatan quantum learning merupakan solusi alternatif dalam memanfaatkan multimedia pembelajaran yang inovatif guna meningkatkan kompetensi siswa Kelas XI SMK Negeri 1 Depok 
pada mata pelajaran akuntansi pajak khususnya materi Pajak Penghasilan (PPh) Pasal 23. Multimedia pembelajaran dengan pendekatan quantum learning dikembangkan menggunakan program macromedia flash CS6 yang hasil akhirnya berupa compact disc (CD) ROM.

Berdasarkan latar belakang, maka rumusan masalah dalam penelitian ini yaitu: (1) mengembangkan multimedia pembelajaran akuntansi pajak dengan pendekatan quantum learning untuk siswa SMK; (2) kelayakan multimedia pembelajaran akuntansi pajak; serta (3) efektivitas multimedia pembelajaran akuntansi pajak.

Dari uraian tersebut, tujuan penelitian ini adalah: menghasilkan multimedia pembelajaran akuntansi pajak dengan pendekatan quantum learning untuk siswa SMK, mengetahui kelayakannya, serta mengetahui efektivitasnya.

\section{Metode Penelitian}

Jenis penelitian ini termasuk kedalam penelitian dan pengembangan atau disebut Research and Development (R \& D). Penelitian dan pengembangan ini bertujuan untuk mengembangkan produk multimedia pembelajaran akuntansi pajak dengan pendekatan quantum learning.

Model pengembangan yang digunakan mengadaptasi dari model Alessi \& Trollip (2001, pp. 411-413), yaitu: (1) perencanaan, (2) perancangan, dan (3) pengembangan. Prosedur pengembangan pada penelitian dan pengembangan ini yaitu sebagai berikut: (1) perencanaan, meliputi: mendefinisikan ruang lingkup, mengidentifikasi karakteristik siswa, mengumpulkan sumber-sumber, dan melakukan brainstorming; (2) perancangan, meliputi: mengembangkan ide konten pembelajaran, melakukan analisis konsep dan tugas yang berkaitan dengan materi, mendeskripsikan program pendahuluan, dan membuat flowchart dan storyboard; (3) pengembangan, meliputi: menyiapkan dan menggabungkan teks, video, audio, gambar, dan animasi dalam adobe flash CS6, menyiapkan soal latihan dan uji kompetensi, melakukan evaluasi formatif dengan alpha dan beta testing, dan melakukan evaluasi sumatif (uji efektivitas).

Desain uji coba melalui dua tahapan pengujian, yaitu evaluasi formatif dan evaluasi sumatif. Evaluasi formatif terdiri dari dua tahapan, yaitu uji alpha dan uji beta. Setelah produk selesai dikembangkan maka dilakukan uji alpha oleh 2 orang ahli media dan 2 orang ahli materi, kemudian dilakukan revisi produk yang pertama. Setelah selesai, dilanjutkan dengan uji beta yang dilakukan oleh siswa. Setelah itu dilakukan revisi akhir. Kemudian produk melalui tahap akhir yaitu evaluasi sumatif dengan melaksanakan pretest-posttest pada siswa SMK untuk mengetahui efektivitas multimedia pembelajaran yang dikembangkan.

Subjek uji coba dalam penelitian dan pengembangan ini yaitu 30 orang siswa Kelas XI Akuntansi SMK Negeri 1 Depok, 2 orang ahli media, 2 orang ahli materi, dan 3 orang siswa dengan kemampuan akademik rendah, sedang, tinggi untuk uji beta. Jenis data yang digunakan dalam penelitian dan pengembangan ini yaitu data kualitatif dan data kuantitatif. Data kualitatif diperoleh dari hasil analisis ke-butuhan dan wawancara pada saat prasurvey. Data kuantitatif diperoleh dari penilaian ahli media, ahli materi, dan siswa melalui angket yang dianalisis secara statistik deskriptif menggunakan skala 5. Data kuantitatif juga diperoleh dari hasil pretest dan posttest siswa.

Data-data tersebut kemudian dideskripsikan sebagai bahan pertimbangan untuk merevisi produk multimedia yang dikembangkan. Selain itu, data kuantitatif dan kualitatif juga digunakan untuk melihat kualitas multimedia agar dapat digunakan dalam proses pembelajaran.

Instrumen yang digunakan dalam penelitian dan pengembangan ini terdiri dari angket, wawancara, tes, dan dokumentasi. Angket ditujukan untuk ahli media, ahli materi serta siswa pada uji beta. Wawancara dilakukan pada saat prasurvey 
dan uji beta. Tes dilakukan pada saat uji sumatif, dan dokumentasi dilakukan dari tahap prasurvey hingga pelaksanaan uji sumatif.

Sebelum divalidasi, kisi-kisi instrumen dikonsultasikan terlebih dahulu kemudian divalidasi oleh 1 orang validator instrumen. Instrumen yang divalidasi meliputi instrumen angket untuk ahli media, ahli materi, dan siswa serta tes gaya belajar untuk siswa.

Untuk validasi instrumen pretest dan posttest dilakukan oleh peneliti dan guru mata pelajaran akuntansi pajak. Validasi dan uji coba dilakukan untuk mengukur dan mendapatkan butir-butir soal tes yang valid dan reliabel. Uji coba soal tes dilakukan di SMK Negeri 1 Depok dengan melibatkan 31 orang siswa kelas XII Akuntansi 3. Jumlah butir soal yang diujicobakan sebanyak 15 soal dalam bentuk pilihan ganda dengan menggunakan 4 pilihan jawaban. Hasil uji coba kemudian diolah dengan bantuan aplikasi komputer Iteman Microcut 3.0 yang menghasilkan butir-butir soal dilihat dari tingkat kesukaran dan reliabilitas sehingga dapat digunakan sebagai soal pretest dan posttest.

Data kualitatif berupa saran, masukan serta kritik dari ahli media, ahli materi serta siswa dihimpun dan disimpulkan untuk memperbaiki kualitas multimedia pembelajaran akuntansi pajak yang dikembangkan. Sedangkan data kuantitatif berupa skor dari ahli media, ahli materi, dan siswa yang diperoleh dari angket yang menggunakan skala likert yang dikonversikan kedalam skala 5, yaitu sebagai berikut: 5 untuk kategori sangat baik, 4 untuk kategori baik, 3 untuk kategori cukup, 2 untuk kategori kurang dan 1 untuk kategori sangat kurang.

Langkah-langkah dalam analisis data kuantitatif yaitu sebagai berikut: (a) mengumpulkan data mentah, (b) pemberian skor, dan (c) skor yang diperoleh kemudian dikonversikan menjadi nilai dengan skala 5 dengan menggunakan acuan yang dikembangkan oleh Sukarjo (2006, p.53).
Tabel 1. Konversi Skor Kriteria Penilaian

\begin{tabular}{|c|c|c|c|}
\hline \multirow{2}{*}{ Nilai } & \multicolumn{2}{|l|}{ Skor } & \multirow[t]{2}{*}{ Kriteria } \\
\hline & Rumus & Rentang & \\
\hline 5 & $\mathrm{X}>\overline{\mathrm{X}_{\mathrm{l}}}+1,8 \mathrm{Sbi}$ & $X>4,2$ & $\begin{array}{l}\text { Sangat } \\
\text { Baik }\end{array}$ \\
\hline 4 & $\overline{\mathrm{X}_{\mathrm{l}}}+0,6 \mathrm{Sbi}<\mathrm{X} \leq \overline{\mathrm{Xl}}+1,8 \mathrm{Sbi}$ & $3,4<X \leq 4,2$ & Baik \\
\hline 3 & $\overline{X_{1}}-0,6$ Sbi $<X \leq \overline{X_{l}}+0,6$ Sbi & $2,6<X \leq 3,4$ & Cukup \\
\hline 2 & $\overline{\mathrm{X}} \mathrm{l}-1,8 \mathrm{Sbi}<\mathrm{X} \leq \overline{\mathrm{Xl}}-0,6 \mathrm{Sbi}$ & $1,8<X \leq 2,6$ & Kurang \\
\hline 1 & $\mathrm{X} \leq \overline{\mathrm{X}} \mathrm{l}-1,8 \mathrm{Sbi}$ & $X \leq 1,8$ & $\begin{array}{l}\text { Sangat } \\
\text { Kurang }\end{array}$ \\
\hline
\end{tabular}

Berdasarkan hasil konversi skor maka diperoleh nilai produk yang dikembangkan. Untuk mengetahui multimedia pembelajaran akuntansi pajak yang dikembangkan efektif meningkatkan kemampuan kognitif siswa maka dilihat dari perubahan nilai siswa dengan membandingkan nilai pretest dan posttest pada uji sumatif.

Uji sumatif dilakukan menggunakan 1 kelas eksperimen tanpa kelas kontrol. Untuk menghitung besarnya effect size pada penelitian ini yang mana hanya melibatkan d (gain). Rumusnya sebagai berikut (Arikunto, 2013, p.277):

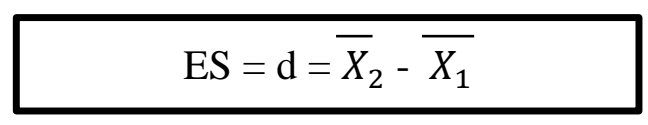

Keterangan:

ES : effect size

$\frac{\mathrm{d}}{X_{2}}$ : gain

$\overline{X_{2}} \quad$ : nilai rata-rata pretest

$\bar{X}_{2}$ : nilai rata-rata posttest

\section{Hasil Penelitian dan Pembahasan}

\section{Hasil Perencanaan}

Hasil perencanaan diperoleh berdasarkan analisis kebutuhan, identifikasi karakteristik siswa, dan penentuan sumber. Berikut ini data hasil analisis kebutuhan dan identifikasi karakteristik siswa yang diperoleh pada saat prasurvey: (1) jumlah materi pajak yang terlalu banyak, (2) perhitungan pajak yang sulit dimengerti, (3) media dan waktu pembelajaran yang terbatas, (4) penyampaian materi yang 
monoton, (5) sebagian besar siswa mengharapkan belajar menggunakan media yang menyenangkan, seperti tersedianya video, colorfull, sesuai dengan gaya belajar masing-masing, serta dapat dioperasikan secara mandiri. Berdasarkan hal tersebut maka diputuskanlah materi yang akan disampaikan menggunakan multimedia pembelajaran akuntansi pajak dengan pendekatan quantum learning yaitu materi mengenai PPh Pasal 23. Sumber-sumber yang digunakan sebagai referensi dalam proses pengembangan multimedia pembelajaran akuntansi pajak didapat dari sumber cetak maupun sumber online.

\section{Hasil Desain}

Kegiatan ini berkaitan dengan pemilihan dan pengaturan konten berdasarkan tahap perencanaan. Berikut ini hasil yang diperoleh: (1) konten pada multimedia pembelajaran akuntansi pajak disesuaikan dengan pendekatan pada aspek-aspek quantum learning, yaitu: kebermanfaatan, lingkungan belajar, gaya belajar, dan teknik mencatat. Penerapan aspek-aspek quantum learning tersebut dalam multimedia pembelajaran yaitu terdapat penjelasan mengenai manfaat nyata mengapa siswa harus mempelajari materi PPh Pasal 23, multimedia yang dikembangkan menggunakan fitur musik, colorfull, dan variatif, terdapat tes gaya belajar untuk mengidentifikasi gaya belajar siswa (visual, audio, kinestetik), materi disampaikan menggunakan konsep mind mapping, dan penggunaan teknik asosiasi (singkatan yang mudah diingat). (2) menyusun soal tes gaya belajar berdasarkan buku quantum learning karya Bobbi De Porter \& Mike Hernacki, menyusun materi PPh Pasal 23, menyusun soal latihan, dan menyusun soal tes akhir (pretest-posttest). (3) membuat flowchart dan storyboard.

\section{Hasil Pengembangan}

Tahap pengembangan ini merupakan hasil produk multimedia pembelajaran akuntansi pajak dengan pendekatan quan- tum learning. Berikut ini adalah poin-poin utamanya.

\section{Opening}

Pembuka/selamat datang bertujuan menyambut siswa sebelum mulai menggunakan multimedia pembelajaran. Selain ucapan selamat datang terdapat juga narator yang menyambut siswa.

Judul

Berisi judul multimedia pembelajaran, target pengguna, nama pengembang, dan nama instansi asal pengembang.

\section{Konfirmasi Tes Gaya Belajar}

Poin ini bertujuan untuk mengetahui apakah siswa sudah pernah melakukan tes gaya belajar atau belum. Disediakan tombol untuk menuju tes gaya belajar apabila siswa belum melakukan tes, dan terdapat tombol untuk menuju ke menu yang sesuai dengan klasifikasi gaya belajarnya.

Penjelasan tujuan tes gaya belajar.

Pada halaman ini dijelaskan mengapa harus melakukan tes gaya belajar terlebih dahulu, yaitu bertujuan agar siswa mengetahui gaya belajarnya. Apakah termasuk kedalam gaya belajar visual, audio, atau kinestetik. Identifikasi gaya belajar ini merupakan salah satu penerapan aspekaspek quantum learning.

\section{Tes gaya belajar.}

Tes gaya belajar terdiri dari 10 soal tes dengan 3 pilihan jawaban, yaitu A, B, dan C. Apabila siswa lebih banyak menjawab A maka termasuk kedalam tipe gaya belajar visual, lebih banyak menjawab $\mathrm{B}$ maka termasuk kedalam tipe gaya belajar audio, dan lebih banyak menjawab $\mathrm{C}$ termasuk kedalam tipe gaya belajar kinestetik. Setelah menjawab semua soal, pada akhir tes ditampilkan hasil yang diperoleh siswa. Cara mengidentifikasinya yaitu dengan melihat jumlah nilai yang paling 
banyak. Apabila siswa memiliki jumlah nilai yang sama pada 2 tipe gaya belajar maka siswa dapat memilih tipe gaya belajar mana yang diinginkan.

Мenu

Tampilan halaman menu untuk semua tipe gaya belajar adalah sama. Halaman menu terdiri dari (1) petunjuk, (2) SK, $\mathrm{KD}$, indikator \& manfaat, (3) materi, (4) latihan, (5) soal, dan (6) profil pengembang.

\section{Petunjuk}

Halaman ini terdiri dari penjelasan icon-icon navigasi, seperti tanda keluar, kembali ke menu, musik, pengaturan volume musik, menuju halaman selanjutnya, dan kembali ke halaman sebelumnya. Multimedia pembelajaran ini didesain supaya siswa nyaman dalam menggunakannya, salah satunya dengan adanya musik klasik sebagai backsound, dimana musik klasik dapat meningkatkan kinerja otak. Kenyamanan suasana belajar seperti adanya musik, tampilan yang menarik, dan colorfull termasuk kedalam aspek-aspek quantum learning.

\section{SK, KD, Indikator \& Manfaat}

Berisi penjelasan standar kompetensi (SK), kompetensi dasar (KD), indikator, dan manfaat. Materi yang disampaikan adalah mengenai PPh Pasal 23 dimana termasuk kedalam SK, KD dan indikator yang sesuai dengan silabus. Adanya tambahan penjelasan manfaat nyata dari belajar PPh Pasal 23 yaitu dijelaskan bahwa materi tersebut akan berguna pada saat siswa melaksanakan Praktek Kerja Industri (PKI). Manfaat nyata ini merupakan salah satu aspek quantum learning, dimana siswa akan lebih tertarik untuk belajar apabila mengetahui manfaat nyata mengapa harus belajar mengenai PPh Pasal 23.

\section{Materi}

Materi PPh Pasal 23 dibagi kedalam 3 kategori, yaitu (1) PPh Pasal 23 teori, (2) $\mathrm{PPh}$ Pasal 23 formulir, dan (3) video PPh
Pasal 23. Untuk kategori materi PPh Pasal 23 teori dan formulir disampaikan menggunakan konsep mind mapping, hal ini merupakan salah satu aspek quantum learning. Penyampaian materi kategori PPh Pasal 23 teori dan formulir disampaikan dengan 3 cara, yaitu (1) penyampaian materi tipe gaya belajar visual, lebih menekankan pada aspek visual (penglihatan), bagan-bagan pada mind mapping ditampilkan secara warna-warni (colorfull), (2) materi tipe gaya belajar audio, lebih menekankan pada audio (pendengaran), selain tampilan materi secara mind mapping, terdapat juga narator yang menjelaskan materi, dan (3) materi tipe gaya belajar kinestetik, lebih menekankan pada gerakan. Selain tampilan secara mind mapping. Siswa diminta untuk meng-klik bagan-bagan pada mind mapping untuk melihat penjelasan materi yang lebih detail. Untuk video PPh Pasal 23 tidak ada perbedaan dalam penyampaian materinya.

\section{Latihan}

Terdiri dari 2 jenis latihan. Latihan pertama berupa soal essay mengenai perhitungan PPh Pasal 23. Siswa diminta mengisi bagian yang kosong (blank space). Latihan kedua, siswa diminta untuk memasangkan keterangan yang tersedia ke dalam formulir yang disediakan.

Soal

Berisi soal tes akhir, terdiri dari 15 soal dengan 4 pilihan jawaban, A, B, C, dan D. Setelah siswa menjawab seluruh soal tes, maka akan tampil hasil akhir nilai siswa disertai dengan balikan (feedback) mengenai hasil yang didapat. Feedback ini merupakan salah satu aspek quantum learning.

Adapun tampilan awal multimedia pembelajaran dapat dilihat pada Gambar 1 . 


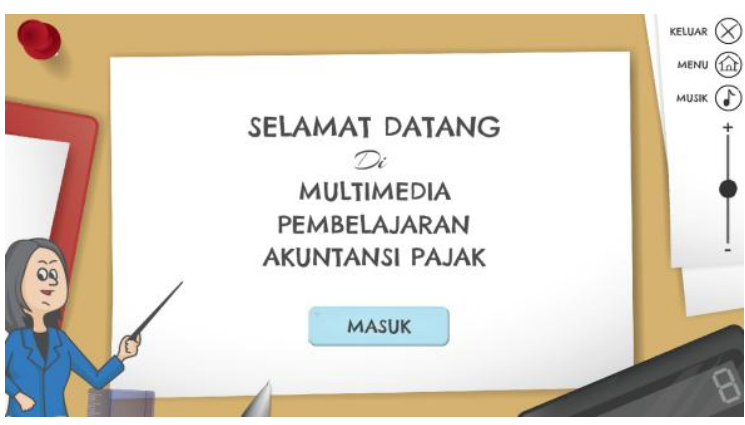

Gambar 1. Tampilan Awal Multimedia

Pembelajaran Akuntansi Pajak

Sedangkan tampilan materi multimedia pembelajaran dapat dilihat pada Gambar 2.

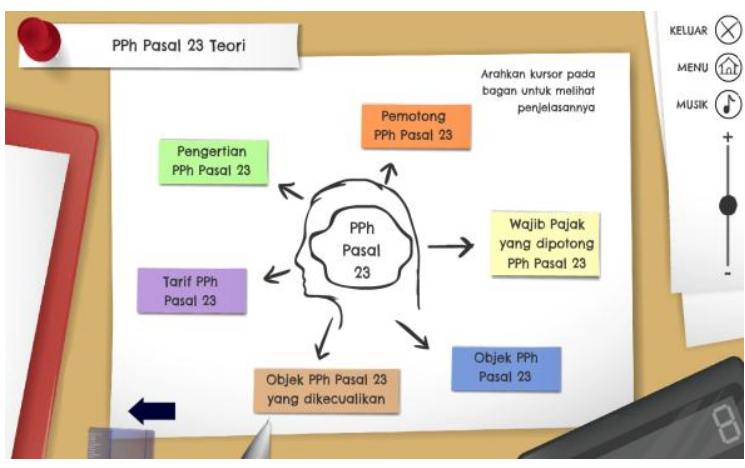

Gambar 2. Tampilan Materi Multimedia Pembelajaran

Hasil Uji Coba Produk

Kegiatan uji coba produk terdiri dari evaluasi formatif dan evaluasi sumatif. Evaluasi formatif meliputi uji alpha (alpha testing) dan uji beta (beta testing), sedangkan evaluasi sumatif terdiri dari tanggapan siswa terhadap produk multimedia serta pretest dan posttest.

Tujuan dilakukannya uji alpha adalah untuk mengetahui kualitas kelayakan multimedia pembelajaran yang dikembangkan. Multimedia pembelajaran ini divalidasi oleh 4 orang ahli. Terdiri dari 2 orang ahli media dan 2 orang ahli materi.

Ahli media pertama yaitu ahli dalam bidang multimedia pembelajaran, $e$ learning, dan pembelajaran teknologi informasi. Ahli media kedua yaitu ahli dalam bidang media pembelajaran masyarakat dan penelitian pendidikan.
Terdapat 8 aspek yang dinilai oleh ahli media. yaitu: (1) aspek informasi tambahan, (2) pertimbangan sikap, (3) hubungan pengguna dengan program, (4) navigasi, (5) pedagogi, (6) fitur tak tampak, (7) kehandalan program, dan terakhir (8) aspek materi tambahan (quantum learning). Kedelapan aspek tersebut dijabarkan kedalam 27 indikator. Data yang diperoleh berupa penilaian, saran dan komentar.

Tabel 2. Rekap Rerata Skor Hasil Validasi Ahli Media

\begin{tabular}{|c|c|c|c|c|c|}
\hline \multirow{2}{*}{ No } & \multirow{2}{*}{ Aspek } & \multicolumn{2}{|c|}{$\begin{array}{l}\text { Ahli } \\
\text { Media }\end{array}$} & \multirow{2}{*}{$\begin{array}{l}\text { Rata- } \\
\text { rata }\end{array}$} & \multirow{2}{*}{ Kriteria } \\
\hline & & 1 & 2 & & \\
\hline 1 & 1 & 9 & 8 & 4,2 & Sangat Baik \\
\hline 2 & 2 & 4 & 3 & 3,5 & Baik \\
\hline 3 & 3 & 24 & 19 & 4,3 & Sangat Baik \\
\hline 4 & 4 & 24 & 20 & 4,4 & Sangat Baik \\
\hline 5 & 5 & 19 & 15 & 4,2 & Sangat Baik \\
\hline 6 & 6 & 4 & 4 & 4,0 & Baik \\
\hline 7 & 7 & 14 & 12 & 4,3 & Sangat Baik \\
\hline 8 & 8 & 27 & 23 & 4,2 & Baik \\
\hline \multicolumn{2}{|c|}{ Jumlah } & 125 & 104 & 33,2 & \\
\hline \multicolumn{2}{|c|}{ Rata-rata } & 4,5 & 3,7 & 4,1 & Baik \\
\hline
\end{tabular}

Berdasarkan Tabel 2, diperoleh ratarata skor untuk aspek media berdasarkan kedua ahli, yaitu (1) 4,2 untuk informasi tambahan, (2) 3,5 untuk pertimbangan sikap, (3) 4,3 untuk hubungan pengguna dengan program, (4) 4,4 untuk navigasi, (5) 4,2 untuk pedagogi, (6) 4,0 untuk fitur tak tampak, (7) 4,3 untuk kehandalan program, dan (8) 4.2 untuk materi tambahan (quantum learning). Untuk rata-rata skor keseluruhan aspek media berdasarkan penilaian ahli media pertama dan ahli media kedua yaitu sebesar 4,1. termasuk dalam kategori "Baik."

Dengan demikian dapat dikatakan bahwa kualitas multimedia pembelajaran akuntansi pajak dengan pendekatan quantum learning ditinjau dari aspek media berdasarkan hasil validasi kedua ahli media adalah "Layak" digunakan dengan beberapa revisi.

Kedua ahli media tersebut memberikan saran dan komentar. Saran dan 
komentar dari ahli media pertama, yaitu: (1) halaman judul harus terdapat judul/ topik, target user (pengguna) dan info pengembang; (2) timer (waktu) tes gaya belajar dibuat dalam format standar. Sedangkan saran dan komentar dari ahli media kedua yaitu: (1) opening terlalu cepat, tambahkan suara narator pada bagian opening; (2) suara narator terlalu lembut dan intonasinya kurang tegas; (3) instruksi pada halaman latihan ditambahkan narator untuk menjelaskan instruksi; (4) halaman opening video dibuat lebih variatif; (5) tambahkan kata "Gaya Belajar" pada kata "visual", "auditori", dan "kinestetik".

Penilaian materi dilakukan oleh 2 orang ahli materi. Ahli materi pertama yaitu ahli di bidang akuntansi pajak, perpajakan, dan akuntansi perbankan. Ahli materi kedua yaitu guru di SMK yang mengampu mata pelajaran akuntansi pajak.

Terdapat 5 aspek yang dinilai oleh 2 orang ahli materi, aspek-aspek tersebut yaitu: (1) aspek pendahuluan, (2) penyajian judul, (3) pendalaman materi, (4) partisipasi siswa, dan (5) aspek penilaian/evaluasi. Kelima aspek tersebut dijabarkan kedalam 23 indikator. Kedua ahli materi memberikan saran dan komentar.

Tabel 3. Rekap Rerata Skor Hasil Validasi Ahli Materi

\begin{tabular}{|c|c|c|c|c|c|}
\hline \multirow[t]{2}{*}{ No } & \multirow[t]{2}{*}{ Aspek } & \multicolumn{2}{|c|}{$\begin{array}{c}\text { Ahli } \\
\text { Materi }\end{array}$} & \multirow{2}{*}{$\begin{array}{l}\text { Rata- } \\
\text { rata }\end{array}$} & \multirow[t]{2}{*}{ Kriteria } \\
\hline & & 1 & 2 & & \\
\hline 1 & 1 & 13 & 12 & 4,1 & Baik \\
\hline 2 & 2 & 18 & 15 & 4,1 & Baik \\
\hline 3 & 3 & 31 & 29 & 3,7 & Baik \\
\hline 4 & 4 & 12 & 12 & 4,0 & Baik \\
\hline 5 & 5 & 20 & 20 & 4,0 & Baik \\
\hline \multicolumn{2}{|c|}{ Jumlah } & 94 & 88 & 20,0 & \\
\hline \multicolumn{2}{|c|}{ Rata-rata } & 4,1 & 3,8 & 4,0 & Baik \\
\hline
\end{tabular}

Berdasarkan Tabel 3, diperoleh ratarata skor untuk aspek materi berdasarkan kedua ahli, yaitu (1) 4,1 untuk aspek pendahuluan, (2) 4,1 untuk penyajian judul, (3) 3,7 untuk pendalaman materi, dan (4) 4,0 masing-masing untuk partisipasi siswa dan penilaian/evaluasi. Untuk rata-rata skor keseluruhan aspek materi berdasarkan penilaian ahli materi pertama dan ahli materi kedua yaitu sebesar 4,0 termasuk dalam kategori "Baik."

Dengan demikian dapat dikatakan bahwa kualitas multimedia pembelajaran akuntansi pajak dengan pendekatan quantum learning ditinjau dari aspek materi berdasarkan hasil validasi kedua ahli materi adalah "Layak" digunakan dengan beberapa revisi.

Berikut ini merupakan komentar dan saran dari ahli materi pertama, yaitu: (1) suara narator terlalu lembut, sound musik terlalu keras; dan (2) uraian materi mengenai PPh Pasal 23 bukan hadiah tetapi penghargaan. Sedangkan saran dan komentar dari ahli materi kedua, yaitu: (1) volume suara narator kurang keras; dan (2) tampilan video diperlebar agar materi terlihat lebih jelas.

Uji beta merupakan uji coba terbatas yang bertujuan untuk mengetahui kualitas multimedia pembelajaran dari aspek pengguna. Uji beta dilakukan oleh 3 orang siswa kelas XII Akuntansi SMK Negeri 1 Depok. Kriteria 3 orang siswa dalam uji beta ini ditentukan berdasarkan kemampuan akademik yang berbeda, yaitu diantaranya 1 orang siswa berkemampuan akademik tinggi, 1 orang siswa berkemampuan akademik sedang, dan 1 orang siswa berkemampuan akademik rendah. 3 orang siswa tersebut dipilih oleh guru mata pelajaran berdasarkan urutan peringkat di kelas.

Terdapat 3 aspek yang dinilai oleh siswa pada uji beta, aspek-aspek tersebut yaitu: (1) pemrograman media, (2) materi, dan (3) pemanfaatan. Setelah itu siswa memberikan saran dan komentar. Ketiga aspek tersebut dijabarkan kedalam 19 indikator. Berikut ini merupakan hasil penilaian siswa pada uji beta.

Berdasarkan data pada Gambar 3 dapat dijabarkan bahwa ketiga siswa memberi penilaian rata-rata sebagai berikut: (1) 4,1 untuk aspek pemrograman media, (2) 4,7 untuk aspek materi, dan (3) 4,6 untuk aspek pemanfaatan. Adapun rata-rata pe- 
nilaian semua aspek yaitu sebesar 4,5. Berdasarkan tabel konversi penilaian termasuk dalam kriteria "Sangat Baik." Dengan demikian dapat dikatakan bahwa kualitas multimedia pembelajaran akuntansi pajak dengan pendekatan quantum learning ditinjau dari penilaian siswa pada uji beta adalah "Layak" digunakan.

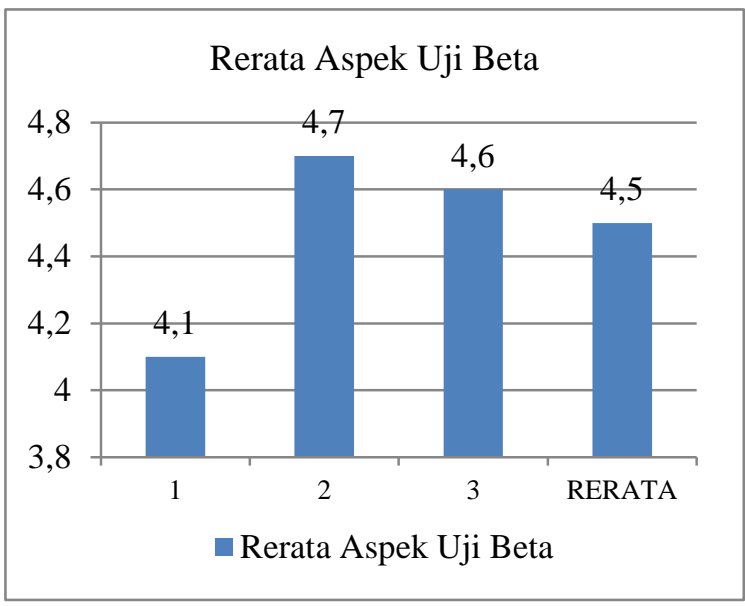

Gambar 3. Diagram Rerata Skor Penilaian Uji Beta

Adapun komentar dan saran dari ketiga siswa yang melakukan uji beta adalah sama, yaitu tulisan di dalam video terlalu kecil dan kurang jelas sehingga sulit dibaca.

Data tanggapan siswa diperoleh dengan cara memberikan angket berskala likert pada siswa untuk menilai multimedia pembelajaran. Angket diberikan kepada 30 orang siswa kelas XI Akuntansi 3 setelah melakukan pembelajaran PPh Pasal 23 dengan menggunakan multimedia pembelajaran akuntansi pajak dengan pendekatan quantum learning.

Terdapat 3 aspek yang dinilai oleh siswa pada uji sumatif, aspek-aspek tersebut yaitu: (1) multimedia, (2) materi, dan (3) pemanfaatan. Ketiga aspek tersebut dijabarkan kedalam 11 indikator. Berikut ini merupakan hasil penilaian tanggapan siswa pada evaluasi sumatif.

Berdasarkan Gambar 4 dapat dijabarkan bahwa siswa memberi penilaian rata-rata sebagai berikut: (1) 3,8 masingmasing untuk aspek multimedia dan aspek materi, (2) 4,1 untuk aspek pemanfaatan. Adapun untuk rata-rata penilaian semua aspek yaitu sebesar 3,9. Berdasarkan tabel konversi penilaian termasuk dalam kriteria "Baik."

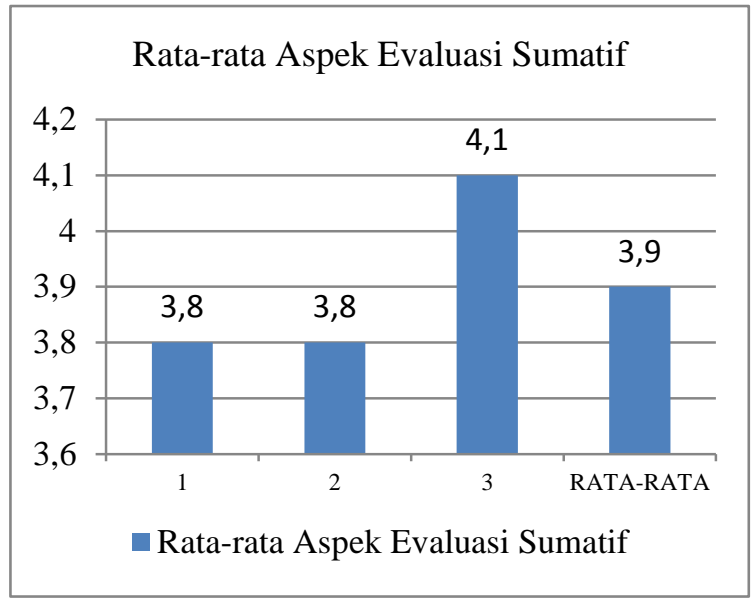

Gambar 4. Diagram Rerata Skor Penilaian Uji Sumatif

Untuk mengetahui efektivitas multimedia pembelajaran dalam meningkatkan pengetahuan dan pemahaman siswa pada pembelajaran PPh Pasal 23 dilakukan dengan cara mengadakan pretest dan posttest kepada 30 siswa kelas XI Akuntansi 3. Soal pretest dan posttest yang dikerjakan siswa kelas XI Akuntansi 3 adalah sama. Berikut ini hasil pretest dan posttest yang dilakukan siswa.

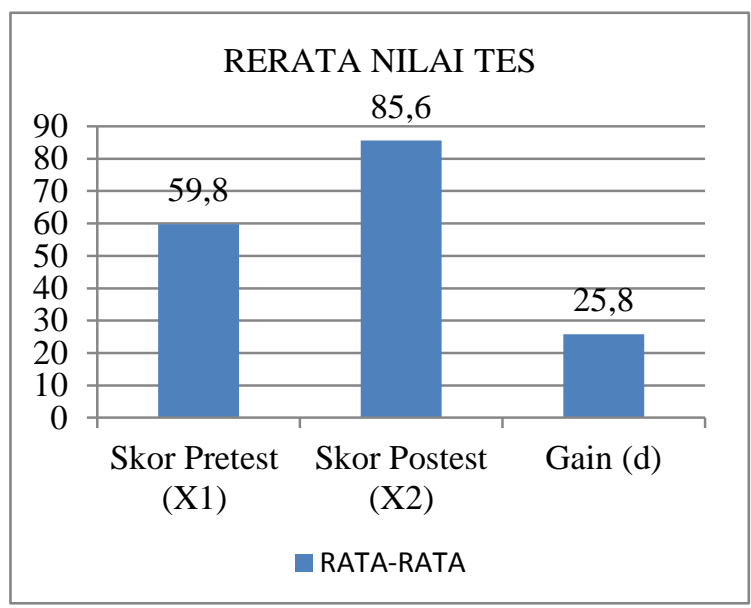

Gambar 5. Diagram Rerata Hasil Tes Siswa

KKM yang ditetapkan adalah sebesar 80 . Jumlah siswa yang tuntas menca- 
pai KKM pada saat pretest adalah sebanyak 2 orang siswa. Sedangkan jumlah siswa yang tuntas pada saat posttest adalah sebanyak 29 orang siswa dan 1 orang siswa tidak berhasil mencapai KKM yang ditetapkan.

Diketahui bahwa rata-rata skor pretest 59,8 dan posttest 85,6 . Dari hasil tes tersebut terdapat peningkatan nilai sebanyak $25,8 \%$. sehingga multimedia pembelajaran akuntansi pajak dengan pendekatan quantum learning dapat dinyatakan efektif untuk meningkatkan pengetahuan dan pemahaman siswa dan dapat digunakan pada proses pembelajaran.

Selain pretest dan posttest, siswa juga melakukan tes identifikasi gaya belajar. Tes gaya belajar ini bertujuan untuk mengetahui gaya belajar siswa. Dimana gaya belajar merupakan salah satu aspek quantum learning.

Gaya belajar siswa berpengaruh terhadap pemilihan penyampaian materi dalam multimedia pembelajaran akuntansi pajak dengan pendekatan quantum learning. Terdapat 3 penyampaian materi, yaitu penyampaian materi untuk gaya belajar visual, gaya belajar audio, dan gaya belajar kinestetik.

Tes gaya belajar ini terintegrasi di dalam multimedia pembelajaran akuntansi pajak dan hanya dilakukan satu kali di awal penggunaan multimedia pembelajaran. Berikut merupakan hasil tes gaya belajar siswa kelas XI Akuntansi 3 SMK Negeri 1 Depok Yogyakarta.

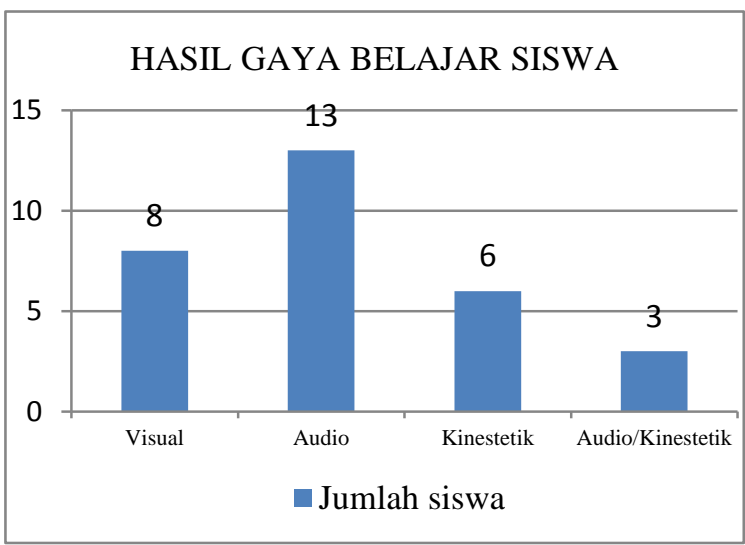

Gambar 6. Diagram Hasil Gaya Belajar Siswa
Berdasarkan data pada Gambar 6 diketahui bahwa dari 30 orang siswa yang mengikuti tes gaya belajar diperoleh hasil 8 orang siswa bertipe gaya belajar visual, 13 orang siswa bertipe gaya belajar audio, 6 orang siswa bertipe gaya belajar kinestetik, dan 3 orang siswa memiliki 2 tipe gaya belajar, yaitu audio dan kinestetik. Nampak bahwa yang paling banyak yaitu siswa yang bertipe gaya belajar kinestetik dan yang paling sedikit adalah siswa yang memiliki dua tipe gaya belajar.

Dengan diperolehnya data di atas, diketahui bahwa siswa memiliki beragam tipe gaya belajar. Oleh karenanya guru dapat mempertimbangkan untuk memilih bahan ajar yang sesuai dengan tipe gaya belajar siswa agar mempermudah proses transfer pemahaman materi pelajaran.

\section{Simpulan dan Saran}

Simpulan

Berdasarkan hasil penelitian dan pengembangan dapat disimpulkan bahwa produk multimedia pembelajaran akuntansi pajak dengan pendekatan quantum learning untuk siswa kelas XI Akuntansi 3 adalah sebagai berikut. Pertama, hasil pengembangan multimedia pembelajaran akuntansi pajak untuk kelas XI dikhususkan pada materi PPh Pasal 23 dengan menggunakan lima pendekatan pada aspek quantum learning, penerapanya yaitu: (1) terdapat penjelasan mengenai manfaat nyata mengapa siswa harus mempelajari materi PPh Pasal 23, (2) multimedia yang dikembangkan dilengkapi fitur musik yang dapat diatur volume-nya, colorfull dan variatif, (3) terdapat tes gaya belajar untuk mengidentifikasi gaya belajar siswa sebelum masuk kedalam materi, apakah siswa termasuk kedalam gaya belajar visual, audio, atau kinestetik, (4) materi yang disampaikan menggunakan konsep mind mapping, dan (5) penggunaan teknik asosiasi yaitu singkatan yang mudah diingat untuk materi mengenai objek PPh Pasal 23. Multimedia pembelajaran ini juga dilengkapi dengan video, latihan, tes akhir, serta balikan (feedback) untuk siswa. 
Adapun fitur-fitur utama multimedia pembelajaran ini antara lain: (1) tes gaya belajar, (2) musik, (3) penyampaian materi sesuai gaya belajar (visual, audio dan kinestetik), (4) latihan, (5) tes akhir (posttest), dan (6) feedback hasil akhir nilai siswa.

Kedua, kualitas kelayakan multimedia pembelajaran akuntansi pajak dengan pendekatan quantum learning menurut ahli dan hasil tes uji beta adalah sebagai berikut: (1) validasi oleh ahli media termasuk kategori baik dengan skor rata-rata 4,1, (2) Validasi oleh ahli materi termasuk kategori baik dengan skor rata-rata 4,0, (3) Validasi oleh siswa dalam uji beta termasuk dalam kategori sangat baik dengan skor rata-rata 4,5 . Berdasarkan penilaian tersebut maka multimedia pembelajaran akuntansi pajak dengan pendekatan quantum learning yang dikembangkan dinilai layak digunakan untuk uji lapangan pada siswa kelas XI Akuntansi 3 di SMK negeri 1 Depok.

Ketiga, multimedia pembelajaran akuntansi pajak dengan pendekatan quantum learning dinilai efektif. Hal ini terlihat dari peningkatan pencapaian hasil belajar kognitif siswa sebanyak 30 orang siswa setelah belajar dengan menggunaan multimedia pembelajaran akuntansi pajak dengan nilai peningkatanya sebesar $25,8 \%$. Sedangkan nilai rata pretest 59,8 , dan nilai rata-rata posttest 85,6 . Terlihat bahwa nilai rata-rata posttest lebih baik daripada nilai rata-rata pretest.

Saran

Berdasarkan hasil penelitian yang disajikan dapat disarankan hal-hal sebagai berikut. Pertama, multimedia pembelajaran akuntansi pajak dengan pendekatan quantum learning untuk siswa kelas XI Akuntansi sesuai dengan silabus dan RPP mata pelajaran akuntansi pajak, serta telah melalui validasi ahli media, ahli materi, maupun uji coba kepada siswa, maka pemanfaatan multimedia pembelajaran ini dapat diimplementasikan oleh guru pada proses pembelajaran akuntansi pajak materi $\mathrm{PPh}$ Pasal 23.
Kedua, guru diharapkan mampu memanfaatkan data gaya belajar sebagai masukan dalam menyusun dan mengembangkan multimedia pembelajaran, sehingga nantinya variasi multimedia pembelajaran yang dikembangkan dapat mengakomodir gaya belajar siswa yang beragam. Selain itu, guru juga dapat menggunakan konsep mind mapping dan teknik asosiasi dalam menyampaikan materi sehingga siswa dapat memahami dan menghafal materi secara mudah.

\section{Daftar Pustaka}

Alessi, S. M., \& Trollip, S. R. (2001). Multimedia for Learning Methods and Development Third Edition. Needham Heights, USA: Allyn \& Bacon.

Arikunto, S. (2013). Prosedur Penelitian Suatu Pendekatan Praktik. Jakarta: Rineka Cipta.

Asmani, Jamal Ma'mur, (2011), Tips Efektif Pemanfaatan Teknologi Informasi dan Komunikasi dalam Dunia Pendidikan. Yogyakarta: Diva Press.

Januszewski, Alan \& Michael Molenda. (2008). Educational Technology A Definition with Commentary. New York: Lawrence Erlbaum Associate.

Sukarjo. (2006). Kumpulan Materi Evaluasi Pembelajaran. Yogyakart: UNY.

Suryani, N. (2013). Improvement of Students' History Learning Competence through Quantum Learning Model at Senior High School in Karanganyar Regency, Solo, Central Java Province, Indonesia. Journal of Education and Practice; Vol.4, No.14, Hal. 55-63. Diambil pada tanggal 18 Januari 2016, dari http://iiste.org/Journals/index.ph $\mathrm{p} / \mathrm{JEP} /$ article/viewFile/6798/6912

Depdiknas, (2003). Pasal 15 Undang-undang SISDIKNAS Nomor 20 Tahun 2003 tentang SMK. 